\title{
LIFE AMONG THE VERMIN: NINEVEH AND ECOLOGICAL RELOCATION
}

\author{
DANIEL WILLIAMS
}

\section{Introduction}

The Assyrian city of Nineveh was situated on the banks of the Tigris River, near present-day Mosul in Iraq, on a fault line unsettled by earthquakes since ancient times. ${ }^{1}$ As capital of the Assyrian empire at its zenith in the eighth and seventh centuries BC, Nineveh was the site of energetic construction by one of its last kings, Sennacherib, who built gated walls, a lavish complex known as the "Palace Without a Rival," and luxurious gardens and parks. He also introduced canals for irrigation, diverted water to reclaim land for construction, and created a marsh to counteract floods, "stocked with the flora and fauna of the Babylonian marshes" (Grayson 114). Neighboring peoples were coerced to labor on such projects, in keeping with broader policies of forced migration in the Assyrian empire. ${ }^{2}$ The sustained aggression of the Assyrians against adjacent kingdoms - the legendary destruction of Babylon's capital occurred during a campaign in $689 \mathrm{BC}$-assured that the later sack of Nineveh in $612 \mathrm{BC}$ was heralded and celebrated by prophets in the kingdom of Judah. ${ }^{3}$ Nineveh appears in the scriptural writings of Nahum, Zephaniah, Isaiah, and later Jonah as a case study in the risks of disobeying God, the dispersal of its once-powerful empire an object lesson in transience. In the Victorian period "rediscovered" by British archaeologists, the ancient city's treasures also embed a narrative of imperial appropriation. Many of its sculptures, cuneiform inscriptions, and stone friezes now grace the halls of the British Museum.

In Nineveh (2011), a novel by Henrietta Rose-Innes, several of these ancient topoi-ambitious construction, mass displacement, land reclamation, and unsound foundations - find fresh relevance in a fable about how spaces and species are blurred in contemporary South Africa. ${ }^{4}$ The novel centers on a pest expert, the aptly named Katya Grubbs, who perversely runs her business on "a strictly no-kill policy" (13). ${ }^{5}$ Katya is drafted into "Nineveh" - a highend, Babylonian-themed residential complex under construction on reclaimed 
wetlands outside Cape Town - to address an elusive insect infestation that emerges from the nearby marshes and threatens the project's existence. An inventive combination of ecological noir, family tragicomedy, and socioeconomic satire, Nineveh catalogs Katya's activities as she discovers how human and insect actors undermine the spatial expectations of post-apartheid South Africa, siphoning off the estate's materials into broader economic and ecological circuits. Nineveh offers an allegory of sorts for a nation-state trying to address novel challenges in spaces and structures haunted by deep-seated inequalities.

I argue that Rose-Innes advances a vision of interspecies connection in Nineveh by recasting controversial themes drawn from South Africa's history - the topoi of "vermin" and "relocation" - to address wider ecological concerns. Although the novel remains alert to vestiges of historical violence and inherited spatial inequality, it thus promotes less a politics for the moment than an ecological ethics rescaled to underscore transience and interchange beyond the human sphere. Rose-Innes first transforms the notion of "vermin" from the imaginary of South African literature and culture under apartheid, where insect life had often furnished images of alienation and racial animus, to present instead a friendly nexus where figurative boundaries among humans and nonhumans collapse. She further describes her protagonist's humane work as "relocation," repurposing another term freighted with the history of racial zoning and forced migration to spotlight networks of beings that defy the structural and spatial confinements of the post-apartheid city. These gestures of reclamation evince a scalar logic that produces a certain tension in the novel's representational texture: they reframe political matters of current or recent provenance to focus on broader and more durable ecological concerns. Having in the first two sections considered Rose-Innes's creative updating of the "vermin" and "relocation" topoi, along with the novel's attendant visions of swarming beings and porous spaces, I address this tension in the final section, discussing how Nineveh tilts these discourses into an ethics of transience attentive to ecological scale. Rose-Innes's representations of acoustic phenomena-specifically of the sonic signatures of human and nonhuman creatures, which disclose alternative imaginaries of infrastructure and temporality-give especially vivid form to the novel's perceptual and scalar refashioning. At first cataloging a comically hopeless effort at "[p]olicing borders" (19), Nineveh ends by uncovering border-crossings at many scales. Together the phenomena described in the essay's three sectionsnamely, the novel's investment in figurative interchange, spatial transit, and perceptual rescaling - comprise what I term ecological relocation.

The success of Rose-Innes's vision of interconnection, I reflect in conclusion, still needs to be reckoned against the tension created by her allusive reframing of these prior historical discourses. If the novel's tonal shift away from "vermin" envisions an ecological relation among humans 
and nonhumans predicated on desire, aesthetic fascination, and vibrant egalitarianism, its metaphors are still reminiscent of the bleaker construal of "aliens" and "invaders" that continues to mark South African culture. ${ }^{6}$ If the novel likewise avoids the containment of beings into rigid zones, rewriting spatial inevitability into an ethics of porousness and flux, its reliance on the fraught notion of "relocation" reveals how social and species interactions are still shaped, and to an extent limited, by historical partitions. In these ways, Rose-Innes adroitly marks out the complexities entailed in using an ecocritical optic in postcolonial contexts, in settings "where practices of nature conservation have so often been linked to political conservatism" and "natural history has so often involved a silencing of social history" (Twidle 52, 58). The novel's investment in the entanglement of human and nonhuman beyond the vermin imaginary aligns Rose-Innes with posthuman ecological discourses that celebrate a decentered "mesh" of beings and "multispecies justice," even as her emphasis on spatial relocation also recalls the human casualties of "slow violence," those "refugees" of environmental degradation and climate change. ${ }^{7}$ Nineveh joins an œuvre, including The Rock Alphabet (2004), the story collection Homing (2010), and Green Lion (2015), wherein Rose-Innes variously navigates the tensions inherent in any literary attempt at ecological relocation. Her work intersects with the politics of environmental and cultural preservation in South Africa, touching on issues like habitat, (de-)extinction, and pollution to canvass the responses of humans to their environments, and to the flora and fauna that populate those environments. ${ }^{8}$ Mindful of human propensities for misunderstanding, appropriation, and destruction, Rose-Innes's vibrant writing is also alert to the possibility of mysterious, preternatural ways of communing with the natural world.

\section{Loving the Unlovely: Beyond the Vermin Imaginary}

Nineveh opens on a scene of relocation, as Katya and her nephew and assistant Toby coax an infestation of caterpillars off a tree and into boxes. The scene is both an advertisement for Rose-Innes's affectionate, miniaturist style, and a brief for an inclusive approach to nonhuman life that permeates the novel's narrative and linguistic texture. "It's strange, what disgusts people," muses Katya: "Who would scorn the friendship of a gecko, for example: golden-eyed, translucent-skinned, toes splayed on a farmhouse wall? Who could resent a long-legged spider, knitting its silver in the corner of a room? But they do: people will pay to have them killed, poisoned, destroyed" (19). Her aims with "Painless Pest Relocations" (13) are sympathetic and recuperative. She strives to "relocate a wasp nest, reroute a caterpillar invasion, clear a roof of nesting pigeons, wrangle housefuls of mangy cats" (19). Katya inherited this line of work from her father, whose harsh approach was more in line with the rest of the population. Wielding his greater knowledge of insect species, Len Grubbs had consigned them to the familiar register of vermin, to be exterminated by 
whatever means available. Katya's "philosophy," by contrast, aims "to respect any creature that gets by in the city": all those "objectionable only because they've wandered from their proper zones, or because they trigger human shudders" (19). Through this fond defense of the nonhuman world, I argue in this section, Rose-Innes aims to undercut the degrading analogies that, in South Africa and elsewhere, have paved the way for violence against humans by turning them, figuratively, into other creatures. The novel's descriptive texture records both the possibilities and the pitfalls of this recuperative gesture.

The deployment of vermin metaphors to characterize specific human populations as vectors of disease had its most notorious and widely discussed showing in twentieth-century Europe, but these notions arguably take their place in South Africa's history as well. ${ }^{9}$ Environmental historians have shown how the construction of animal predators (especially jackals) as "pests" had an important place in the fashioning of South African farming and conservation practices in the late nineteenth and early twentieth centuries (Beinart 195-234; van Sittert, "'Keeping the Enemy at Bay"). The Afrikaans term for "vermin" (ongedierte, from dier, "animal") separates such animals from themselves, conveying "the idea of a non-animal or de-animalized creature" (Beinart 207) to be hunted without mercy. Indeed, organized vermin exterminations co-opted many of the same genocidal techniques that had previously decimated San hunter-gatherer populations on the colonial frontier (van Sittert, "Genocide"). At the turn of the century, too, black Africans were being cast as a "social pest" (Swanson 391), the target of sanitation and quarantine practices that adumbrated apartheid techniques. This broader discourse had repercussions for the treatment of human beings after 1948, as testimonies to the post-apartheid Truth and Reconciliation Commission retrospectively documented. ${ }^{10}$

These historical nodes are necessarily schematic, but in South African literature produced under apartheid we can nonetheless detect a thorough deployment of what could be thought of as a vermin imaginary, converting animals and insects into indices of alienation or racial difference. Echoes of Franz Kafka are more audible here than those of Charles Darwin, on whose letters Rose-Innes draws for a warm epigraph about "the capturing of rare beetles" (7). In Alex La Guma's novella, A Walk in the Night (1962), representations of the township qua organism underline the horror of such an imaginary:

In the dark corners and the unseen crannies, in the fetid heat and slippery dampness the insects and vermin, maggots and slugs, 'roaches in shiny armor, spiders like tiny grey monsters carrying death under their minute feet or in the suckers, or rats with dusty black eyes with disease under the claws or in the fur, moved mysteriously. (32)

When the township characters in Sizwe Bansi is Dead (1972), Athol Fugard's collaboration with John Kani and Winston Ntshona, are faced with the similar 
situation of purging a photography studio of cockroaches, they know what to do after the insecticide "Doom" fails: find a cat (157-59). Nadine Gordimer's work uses insects swarming, singing, and dying as a motif for multitudes inhabiting a harsh historical landscape. The white family fleeing in July's People (1981) feels oppressed by the locusts, cockroaches, millipedes, and flying ants populating the rudimentary refuge provided by their black servant (47-49). In A Guest of Honour (1970), the "ear-ringing racket" (49) of insects is pervasive and their "broken-bodies and strange-coloured innards" (77) smear vehicles. One character in A Sport of Nature (1987) ponders Fyodor Dostoevsky's The Brothers Karamazov and its frank alignment with "insects" rather than "angels" (109). Finally, in a story about an amputee who contemplates a locust that has also lost a leg, this brief ground for kinship and sympathy among him, his wife, and a creature with "the same trouble" ("Soft Voice" 6) is erased when it flies away and reestablishes its mobile alterity.

Even in the work of J. M. Coetzee, one of Rose-Innes's writing mentors, the place of insects tends to be eclipsed by an ethical focus on larger nonhuman creatures. In his first work, Dusklands (1974), Coetzee embeds a philosophical reflection on a beetle described as a "true creature of Zeno" because it is all exteriority, a set of receding surfaces that do not reveal an inside even in death: "It is only when you pull the head off his body that a tiny insect shudder runs through him; and this is certainly involuntary" (96). A respondent to Elizabeth Costello in The Lives of Animals (1999) later recapitulates this view, positing that, "To an insect, death is the breakdown of systems that keep the physical organism functioning, and nothing more" (64). Insects are nevertheless a crucial feature of the Western Cape landscape that figures especially in Coetzee's earlier work. The Kafka resonances are prominent in Life \& Times of Michael $K$ (1983), where people fleeing cities racked by civil unrest are on "cockroach pilgrimages" (105), and the novel's curious protagonist, described as a "stick insect...whose sole defence against a universe of predators is its bizarre shape" (149), tries to live on the land with minimal intrusion, with a touch as light as "the scratch of ant-feet" (97). Here and elsewhere the vermin topos is key, even if Coetzee's representations are framed to undercut it: the imperial aggressor in Dusklands boasts about having "presided over the becoming number of ten thousand creatures, omitting the innumerable insects that have expired beneath my feet" (80); the narrator of Foe (1986) remarks on how Cruso and Friday viewed apes as "a pest" and "killed them whenever they could, with clubs, and skinned them, and cured their pelts" (21); the Magistrate in Waiting for the Barbarians (1980), upon being taken violently into custody for defending the humanity of the Empire's prisoners, realizes "that we crush insects beneath our feet, miracles of creation too, beetles, worms, cockroaches, ants, in their various ways" (107).

Insects thus work their way persistently into the South African literary imaginary. Yet the unpalatable tenor of the foregoing examples is a far cry 
from a novel whose humane protagonist sees her "job" as "helping...small sojourners in a strange land" (19). Where the writers above draw on the vermin imaginary to fund allegories that are bleakly critical of racial segregation in South Africa, Rose-Innes tilts away from such concerns and attends instead to a different order and tonality of interaction among humans and nonhumans. It is with an admiring warmth that she reflects, in an interview, on how "insects and other 'vermin' are humble and despised, but powerful in numbers," the "underdogs of our city ecosystem," the "underbeetles" ("South African"). RoseInnes draws on the vermin imaginary, I contend, in resourceful ways that are sensitive to the visual charm, perceptual acuity, and self-organizing vibrancy of insect (and other nonhuman) worlds. Perhaps a more apposite reference point for her approach would be Léopold Senghor's provocative defense of an African epistemology that is participatory and dialectical, bridging the subjectobject distinctions of post-Cartesian philosophy by means of a subject who, "at the tips of his sensory organs, his insect antennas...discovered the Other" (72).

Nineveh's openness to the nonhuman world as a space of wonder, curiosity, and allure has a strong effect on its porous figurative language: human, animal, insect, and plant descriptors freely combine. Toby has "spidery limbs" (11) but also "a kind of springy resilience, like green wood," and there is a "vegetable greenness of the veins beneath his skin," matching his "slightly sappy body scent" (20). He and his girlfriend Tasneem appear as "pretty insects," "little garden helpers, mandibles moving" (141). He is "lean and long, with those giant eyes and triangular chin, mantis-like"; she is "beetle-like, glossy, busy" (141). Zintle, the assistant to Nineveh's developer Martin Brand, is described as "glossy and round and fragrant as a sugar plum," and speaks with "a flick of butterfly eyelid in every syllable" $(36,38)$. Such figurative blends also extend to plants and inanimate objects: we watch a "centipede of trolleys" (99) at the mall; bulldozers on a break are "excavating beasts [that] have clamped their jaws and rested their topsoil-bearded chins on the ground" (27); a "bluegum, pale-skinned and statuesque" is carved up by chainsaws, men subsequently "hauling the pieces away like joints of meat" (26). Although this stylistic technique has been neatly described under the Deleuzian rubric of "becominganimal" (Menozzi 195-96), in my view it also operates to introduce a slippage among human and nonhuman domains while instituting an obliquity in matters of racial representation. Although her character names and other brief details still function as tacit racial markers, Rose-Innes otherwise maintains a certain diffidence about race, in contrast to the literary instances of the vermin imaginary above. ${ }^{11}$ At the same time, her figurative ellipses seem to argue the salience of other representational continuities across human and nonhuman bodies. ${ }^{12}$

Such figurative suppleness also motivates Nineveh's probing attention to the (human) body as a locus of intimacy, historical damage, and sympathetic acuity. The scars on Katya's skin are records of a childhood at the mercy of 
a father by turns careless and cruel: "He never could respect the fragility of bodies" (77). They make clear that the alterable surface of the body contains a signifying system, an "expressive alphabet" (81) that tells of personal history. Again, questions of race are deflected somewhat to focus on how the skin records interactions with other species, an exchange of matter with dogs, snakes, spiders, and ticks that Katya and her father have in common, and that further undergirds the novel's metaphoric miscegenation. He has a snakebite scar, for instance, that resembles "the smooth skin of a gum tree where the bark's stripped off" (100). Deftly aligning the intimacy that enables desire and sensitivity as well as violence, Rose-Innes calls attention to Katya's marked skin as an embarrassment when surveyed by passing lovers, in one recollected scene (81), but also as a membrane that promotes sympathetic communion with other perceptual modes. ${ }^{13}$ Returning to Nineveh and hearing the vital presence of frogs on the marshes, Katya responsively takes on an amphibian quality, feeling her "frog skin...wet and alive" (150).

Nineveh's depictions of humans and other creatures can thus be warm, disarming, and figuratively enmeshed, its images calling forth registers of eroticism, tactility, and sympathetic awareness. Yet at moments it is unclear whether the novel's metaphoric resourcefulness and wider tragicomic tenor can wholly reclaim the discourse of vermin. Katya may ponder writing a memoir entitled "Life Among the Vermin" (47), and among the many group nouns for the variety of nonhuman creatures that wander through the novel there are some fond terms: "caravan" (12), "congregation" (13), "gatherings," and "migrations" (19). But there are also familiar surrogates for xenophobic contagion, terms unable to discern their objects as other than threatening aggregates: "abomination" (9), "swarm" (11), "stampede," "infestation" (12), “corps" (24), "army" (175), "immigrants," "newcomers," and "troublemakers" (143). Katya's work makes her a supporter of "squatters and invaders" (19) in many-legged form, but there are limits to her sympathy in both nonhuman and human directions. She praises the sympathetic imagination of attaining a "[p]est's eye view," although what humans can accomplish in this respectwe can "get down on all fours, to emulate the beasts" (109) — surely raises a difficulty when the objects of sympathy have six or eight, hundreds or thousands of legs, not to mention wings, compound eyes, and other starkly different modes of motion and perception.

Katya's attempt to commune with nonhumans also makes her perforce less attentive to human nomads, to the "damaged and abandoned" (29) of the city. A vagrant named Derek lurks around her apartment, an allusion surely to Coetzee's Age of Iron (1990), where a similar character becomes an unlikely companion for the elderly protagonist. However, Katya merely tolerates Derek and his crew, having "never given them more than an empty Coke bottle to return for deposit" (30). There is little of Mrs. Curren's strident defense of Vercueil as "not a rubbish person," or of her broader protest: "There are no rubbish people. 
We are all people together" (Coetzee, Age of Iron 47). This differential regard accorded to nonhumans in Nineveh might be characterized as a strength and not merely an omission, however. If the novel maintains a tender openness to its crawling and flying populations at the level of figure and style, that is, it avoids the glib conclusion that this linguistic bulwark against the threat of a vermin or pest discourse might always forestall degrading treatment, or that shifts in language necessarily make for more open or sympathetic interaction among human beings.

\section{Trade Routes: Relocating Ecological Space}

This free blending of human and nonhuman worlds at the level of language presages a more complex interpenetration at the level of space, in the novel's representation of urban ecology and its historical determinants. As I claim in this section, Nineveh endeavors to recast the cartographic legacies of apartheid by adding an ecological layer to the topos of relocation, trying to unsettle the spatial and scalar imaginaries of Cape Town's urban geography. Again, the novel's allusive representations probe the limits as well as the successes of this reframing.

The process begins when Katya receives a commission to rid the Nineveh complex of its shadowy infestation, travels to the estate to investigate, and almost loses her way. The property is "not in the Cape Town street directory" (51) and does not quite correspond to the physical map or the city's intuitive orientation. We are not given an exact location: Rose-Innes's descriptions of a beach backed by protected wetlands "somewhere out past Noordhoek" (51) puts the estate south of the city, another step in the spread of Cape Town's suburban sprawl. Eventually Katya finds this marvel of Mesopotamian kitsch, its ziggurat buildings cascading in white stone, complete with palm trees, lion sculptures at the gates, and "white walls on either side, topped with electrified wire and set with evenly spaced floodlights" (51-52). Her fingerprints give her access to the complex and her room in Unit Two. As one of the guards puts it, Katya is "in the system": she feels "already built into the fabric of the building," as though "her whorls and loops were there on the blueprints, inked in, microscopic" (55).

Nineveh is purportedly shielded from unwanted natural and human incursion; it aims to be "exclusive" in both senses of the word. Such a partition of space is not so straightforwardly achieved. Outside "Nineveh's perimeter," we are told, "everything is insistently alive and pushing to enter" (62). Katya encounters beyond the walls "[a] watery patchwork place, shifting and uncertain" (74), and realizes that reclaiming the wetlands for the estate was useless, since "rising water and its travellers always find a way back in" (62). Nineveh cannot escape an interspecies contest that pervades Cape Town and its highly biodiverse Cape Floristic Region (colloquially known after its fynbos vegetation). The provenance of species is a persistent source of cultural 
anxiety here (Kruger 17-18; Comaroff and Comaroff 637-39). It is striking that the fictional binomial Rose-Innes reveals for her shimmering blue-green beetle species, "Promeces palustris" (102), denotes a wetlands creature (from the Latin palustris, "marsh": a term used in Linnaean taxonomy). Although a headache for Nineveh, these creatures are thus autochthonous, not technically invasive, at home in their "pure Cape fynbos" (62) environs. ${ }^{14}$ Beyond the wetlands, the mountain that anchors the city is also, especially since the nineteenth-century importation of species from the British Empire, "all contested territory, overlapping, three-dimensional, fiercely patrolled" (24). Rose-Innes's description of "[m]illions of miniature turfs, the size of [Katya's] palm, of her footprint, her fingernail" (24) deftly condenses two senses of "turf"- ground cover and protected domain - and conveys the diversity of the area's ecosystem in images that also speak to the threats posed by hands, feet, and fingernails that would annex "turfs" for their all-too-human benefit. ${ }^{15}$

By contrast, in its representation of interlocking spaces and perceptual orientations, the novel typically casts human projects as superficial and temporary. Katya's professional alignment with creaturely viewpoints attracts her to spaces that flank, undergird, or rescale human architecture - to the "inbetween feel" (34) of parking garages or the "grubby topside" (36) of city roofs. The parallels between spatial orientation and psychic depth are important in Nineveh as in Rose-Innes's wider work, where infrastructural themes often occur. ${ }^{16}$ She stresses the "sense of downness": "The roots of the city, after all, do not run deep. A few metres down, and there you have it: raw earth, elemental....Depth, which the city conceals with its surface bustle. You forget what's underneath. A sudden vision of the deeps beneath the city, alive with a million worms, with buried things" (29). Intuitions of a subterranean world, a creaturely underground, figure another inescapable space, a zone of psychic and historical repression.

Despite Katya's initial cartographic confusion, the estate's location, architecture, and security system typify one arrangement of post-apartheid space, with its gated enclaves and quasi-military armed response patrols. ${ }^{17}$ Yet by setting this luxury development next to a teeming ecosystem that it struggles to keep separate, while characterizing the city as barely an integument covering the creaturely underworld, Rose-Innes adds an ecological density to South Africa's vexed history of spatial organization. To get a measured assessment of this gesture requires adding historical depth to the notion of relocation, here redesigned as a neutral term to match Katya's "painless" rescue operations. In apartheid South Africa, the 1970s and 1980s had seen a concerted effort to coerce people into racial cantons, an intensification of earlier spatial separations (especially urban "influx controls" from the 1950s onward). This process was variously euphemized as "relocation" and "resettlement," and in contemporaneous sociological work the displaced were characterized as "discarded people" (Desmond) or "surplus people" (Platzky and Walker), 
terms to which Coetzee's "rubbish people" (above) alludes. During the 1990s transition to a post-apartheid government, progressive plans to desegregate cities, upgrade townships, and replace informal settlements with affordable housing were abandoned in favor of a neoliberal approach to housing policy in urban areas. ${ }^{18}$ Since 1994, in line with this market-friendly and deregulatory agenda adopted by the government, practices amounting to a reinvention of state-sponsored relocation have emerged: campaigns to demolish the shack settlements that burgeoned on the urban periphery as apartheid's zoning controls were lifted; evictions and coerced relocations that make way for inner-city commercial and real estate development, thereby burnishing the "world-class" allure of South African cities; privatization of public spaces and municipal services. ${ }^{19}$ These practices, which show no signs of abating, have been described as effecting a transition from racial to class apartheid (Bond 99, 198-239). In Cape Town specifically, "arguably [South Africa's] most uneven and spatially segregated city" (McDonald xviii), such practices have been bolstered by an official Anti-Land Invasion Unit (formed in 2009), and also resisted by grassroots groups such as the Western Cape Anti-Eviction Campaign (formed in 2000) ${ }^{20}$ But historical divisions in urban space have largely been maintained. ${ }^{21}$ In the novel, for instance, the estate's developer and Katya's sister live, respectively, in Claremont and Constantia (20, 25), affluent suburbs whose property prices were elevated by apartheid-era removals that would later make Cape Town capable of "attracting a transnational elite" (McDonald 152). ${ }^{22}$

With its real estate centerpiece (a typical outgrowth of South Africa's neoliberal urban policy) and its reference to relocation, Nineveh alludes to both apartheid removals and continuing post-apartheid evictions. However, in updating these themes to include in the concept of relocation what have been termed "developmental refugees"- those forcibly moved to make way for more lucrative properties or the infrastructural vanity projects of postcolonial states-Rose-Innes further records the ecological cost of such practices. ${ }^{23}$ The novel embodies "the way a deregulated, environmentally hubristic neoliberal order imposes new enclosures and thereby generates new nomads" (Nixon, "Neoliberalism" 597). Its protagonist has been neatly termed "a specialist in pest gentrification" (Bady) and her work might be understood as allegorizing larger shifts in urban demographics. Katya wonders, for instance, "how many thousands of vertebrate and invertebrate souls were displaced or destroyed" (61-62) in the building of the estate. Earlier, she recalls the city takeover of a park, giving a documentary view of how such activities disrupt human and other ecosystems: "uniformed guards also removed the park's human dwellers...their blankets and mattresses like misshapen fungi pulled from the soil" (26). Such scenes refer to continuing state-sponsored actions against squatters in South African cities (cf. Kruger 25-26) while adding an ecological dimension to the discourse, even though, as I intimated above, 
their sympathetic ethos is hampered by an aggregative approach that pools individual sufferers together.

Keeping in mind what lurks beneath the term relocation, the ecological porousness of Nineveh and its surrounding wetlands can be connected to the socioeconomic contest in which it is also engaged. The estate's site near the well-heeled and picturesque suburb of Noordhoek, with seemingly easy access to a population of service providers and construction workers, exemplifies the tenacious class stratification of Cape Town into richer suburbs abutting Table Mountain, the coast, and areas around the historic center, and poorer suburbs and townships on the Cape Flats. Elsewhere in the novel Rose-Innes comments on a similar juxtaposition of isolated preserve and informal settlement: the Wolfgat Nature Reserve borders Cape Town's largest township, Khayelitsha (122), assembled in the 1980s. In the neoliberal vision of Nineveh's developer, Mr. Brand, this haven for wealthier Capetonians will be one of many "luxury estates" (84) serviced by "informal settlements" bordering such complexes, which will in turn - following post-apartheid neoliberalism's perennial claim that social problems have market solutions - benefit from jobs, "better homes, roads, electricity" $(85){ }^{24}$

Such zones were always even less likely than the wetlands to remain cordoned off from the luxury so garishly on offer inside. On a walk outside the property, Katya makes her way along the road to a nearby mall, and wonders about the networks that end in roadside stalls selling wares. Glimpsing some tiles for sale that are identical to those on the estate, she buys a few and bribes the seller to show her where they came from. Under a boardwalk that stops abruptly in the middle of a field, which Katya had noticed on an earlier stroll, she is now shown a barely noticeable space where a "tunnel seems to go right under the perimeter wall, under the caretaker's building" (108), revealing "another, lower storey, an underneath that did not exist before" (109). This, Katya vaguely understands, is the site of "channels" (110) that penetrate Nineveh, literal paths and virtual circuits that lead into "a wider ecological and economic flow of circulation, transmission, and exchange" (Menozzi 196). Just as the settlements she has walked past are "sewn together by taxi routes and shortcuts through the bush" (123), and as the stalls are linked up into some larger informal economy, so the shiny estate has "trade routes out and in" that connect the swarming movements of insects with the "illicit transactions" of human actors (110).

It takes Katya some time to realize that the connection between these nonhuman and economic relays is direct. In fact, it turns out that her father, whom she comes across at the mall, is mediating the whole nexus. Having received the first, failed commission to deal with the Nineveh infestation from Mr. Brand, Len has now remained behind as his own "insurance" (18) (his appropriately market-based term for the practice of leaving some specimens alive after a given extermination, to guarantee future work). In cahoots with 
one of the guards - not coincidentally another nomad, an immigrant from the Democratic Republic of Congo-Len has been squatting in the unoccupied Unit One beneath Katya, curating a new hatch of larvae while also making use of the subterranean tunnel to hoard the estate's building materials for later sale. The return of a historical repressed in the novel - the topos of relocation bequeathed from apartheid removals to post-apartheid spatial controls - is thus, at a turning point in the plot, displaced by the reappearance of a familial one.

\section{Soundings: Towards an Ethics of Transience}

Katya comes to realize both Len's secret presence and his connection to the estate's literal undermining by means of another of the novel's stylistic peculiarities, its persistent recording of acoustic phenomena. Rose-Innes tracks strange pulsations of sound through objects and surfaces, outlining unexpected ways in which infrastructures overlap and cataloging types of sounds that identify (or mark as unidentifiable) human, nonhuman, and inanimate entities. The use of sonic markers presages a more radical relocation of time as well as space and a more attentive characterization of nonhumans beyond vermin. Sound, I suggest in this section, offers a template for the novel's approach to merging these preceding discourses: Nineveh formulates an ethics of transience that frames human worlds against wider existential and ecological concerns without erasing the topoi of historical and ongoing injustice.

Much of Rose-Innes's work from Shark's Egg (2000) onwards is alert to sound, noise, and silence, but Nineveh's acoustic range often outstrips its considerable visual richness. Sound demarcates space and differentiates actors in the novel's midst. We hear the "damp sound" or "dry scuttle" (12) of different insects, the "tearing noise" (60) of a goose lifting off water, the "gruff dark-chocolate" (87) sound of the dog Soldier, and the ominous "Scritch, scratch" (90) (also a chapter title) that it is Katya's mandate to identify. In another version of figurative overlap we also hear the "irregular ting ting" (53) of a guard's bicycle, the "Thwuck" and "Thwop" (79) of Mr. Brand driving golf balls off the estate's roof, the "riff of meaty pops" (99) and the "metallic gushing" (111) of Katya's father cracking his knuckles and urinating. RoseInnes has countless instances of such bravura onomatopoeia. She also switches language for acoustic effect, calling on the evocative Afrikaans word "tjoepstil" (91) ("quite quiet").

Indeed, "upholstered silence" (64) is precisely what Katya meets at Nineveh. Her room is both spatially segregated and acoustically muffled. Exterior sounds are minimized_- "sound sinks into the air like a footfall on thick carpet" (57)—whereas insulation amplifies interior noises, so her heartbeat becomes "a scraping sound, too loud" (58). But Katya is aware, from her passage into the estate, that there exists "a hidden chorus, multitudinous, massed in the night: the creaks and sighs and bellings of the creatures out there 
in the vlei," those "she's come to parley with" (54). She also hears "floating sounds of human life" in the evenings: "A radio, a crying child, companionable shouting" (87). The novel's sonic motifs level out aspects of the South African literary tradition into a vision of interspecies connection. Unlike in Gordimer's July's People, for instance, where the "ringing of insects enfeebled the single, long undifferentiated cry, made up of singing, thudding, human to-and-fro" (47; emphasis added), the human sounds beyond Nineveh form "a fragile symphony" with the "densely patterned chorus of frogsong" and the ocean as "a distant bassline" (87). Yet the tensions I have brought out in the previous two sections remain. Referring to creatures variously "chattering," "scuttling" (118), "clicking" (91), "growling" (186), and "clucking" (90) their way through the novel - alongside humans who give a "snort" (147) or "bellow" (129) makes audible the risk of blending individuals into aggregates. Onomatopoeia has its reductive side: a slang term for foreigners that came into wide use during the xenophobic attacks of 2008, makwerekwere, purportedly mimics (like the Greek-derived "barbarians") the incoherent mumble of non-native Africans in South Africa.

Before long these overlapping noises come to reveal their human and nonhuman connections, and their role in undermining the material structure of the estate. The detective possibilities of sound appear early on when Katya, in the bath, hears "noises coming through the wall" (29), in the same way as she often makes a mental note of the sounds of homeless people in the alley outside. Such domestic scenes connect sound to more expansive themes of spatial disintegration and the threat of unstable foundations. The noise of construction across the way is related to the widening cracks in Katya's house, "the odd warp and split, the plaster running like a laddered stocking" in "long italic slants" that might be read as "seismograms" (43). "No wall is ever silent," a narrator's aside reads, flagging the connection between sonic rhythms and the transient ebbing of time:

always there is a subdued orchestra of knocks and sighs and oceanic rushing. The hum of pipes, the creaks of bricks and mortar settling. Or unsettling: such sounds are the minute harbingers of future destruction, the first tiny tremors of a very, very slow collapse that will end, decades or centuries from now, in a pile of rubble. (91)

Since neither infestation nor structural weakness is immediately perceptible at Nineveh, Katya must become more attuned to what might be audible in this habitat, each night consulting a "mental archive of pestilential noises" (90) and "echolocating" (91) by putting a glass to the walls. As the novel dims the lights and flirts briefly with horror, one night stands out. Katya's unit starts to seem "more like an ear: whorled, attentive, magnifying every faint sound" (111) and she hears what should be impossible, given the fingerprint lock on her door: human footsteps inside. In the morning, she finds a colorful frog in 
the bathtub, a coded signal from her childhood that indicates that her father has somehow gained access to the property and intends to play a part in what follows. Katya tries to pass off the (common) frog as endangered to weasel a permanent contract out of Mr. Brand, promising to safeguard the estate's "complex ecosystem" (147), but this only serves to bring all the novel's actors together for a muddy, chaotic finale.

In returning to Nineveh in time for the first rains and a direct confrontation with Len, Katya is shown his squatter's digs, the room in Unit One that connects by means of a trapdoor to the subterranean tunnel that Katya saw leading under the boardwalk. This is both a storage space for the "stripped-out ornaments and accoutrements" that Len is selling off as he participates in that respectable postcolonial occupation, "import/export," and a "portal" (164) for any number of creatures to enter and spawn. It is a "strange dim auction-house for subterranean beings, or a kind of museum, a catalogue of objects from the daylight world" (164). In spatial terms that echo earlier descriptions of the city, it is "[a]n in-between place, where things overlap, where the vlei steps inside and the indoor world escapes into the wild" (163). If one reorientation of South African writing about the city has followed Michel de Certeau's binaries of cartographic and pedestrian (Titlestad 678-79) - the apartheid surveyor replaced by the nomadic walker, the bird's-eye view trumped by the street-level experience - in Nineveh a more dramatic reconfiguring of space occurs. ${ }^{25}$ The upside-down geometry of the estate gives the impression that its "architecture seems to have proliferated" (185), and space seems to take on sonic qualities: folding, vibrating, and echoing. Similarly, Katya senses an "odd curvature of space...leading her in circles like Alice in the flower-garden" and wonders whether it is "physically possible to wade straight through to the other side, to get back to the map" (74).

Rose-Innes's representation of looping paths recalls a useful distinction between kinds of space drawn by Gilles Deleuze and Félix Guattari: "a smooth (vectorial, projective, or topological space) and a striated (metric) space" (361$62) .{ }^{26}$ Nineveh is set up along the lines of striated space: its organization relies on architectural surveys and blueprints, the "grids and generalized parallels" of agriculture and landscaping, and the geometry of state power that sets out "to control migrations and, more generally, to establish a zone of rights over an entire "exterior"' (Deleuze and Guattari 384, 385). By contrast, the beetle infestation traverses smooth or "nomad space," overflowing the boundaries erected to separate plotted human habitation from marshy nonhuman habitats, "gnawing away at" and "gaining ground on" linear space in the service of "vortical," "curvilinear" flows (Deleuze and Guattari 384, 361). Although her representational practice works in a warmer and more approachable tone than such theoretical speculations, Rose-Innes is everywhere attentive to the chaotic and nonlinear, from the "loops and forks" (51) on the map that confuse Katya about her hometown, to the "arabesques of mud" (55) that adorn 
Nineveh's walls, to the "whorled" (111) rooms and walls that coil together interior and exterior. ${ }^{27}$ These representations undergird what I am calling an ethics of transience: they aim to comprehend a sort of ebbing away of space as well as time that radically rescales human worlds even as vestigial barriers are disclosed. These weird contortions of space further track warrens and paths carved out by nomads of various species, restoring a nonhuman presence in, around, and crucially under city structures. ${ }^{28}$

In a social and ontological hierarchy that is muddled as soon as declared, the estate discloses a "middle world, lying beneath the clean light and sumptuousness of Unit Two," and then "an even danker world: the crawlspace under the building" (164). Sound and space overlap as the beetles finally emerge from this space, in the rain, and "the insistent rhythm of the swarm, its secretive white noise" (177), becomes impossible to ignore. They crawl into Unit One and spread out through the estate until its "whole surface is alive with tiny creatures, stirring, swarming" (173). In the novel's final confrontations, Katya allows a guard dog to be unleashed on her father in a moment of wicked revenge for the casual violence to which he has long subjected her and her sister, but he is spared a harsher fate through his business connection with Nineveh's security guard. Mr. Brand follows them all down to Unit One, accidentally stepping on rotten floorboards and falling "through a hole in the world" (189). Katya is left to disengage her client and they wade out, through the mud, emerging in the storage space where Mr. Brand sees what Len has been thieving.

A series of reflections on the limits of segregation and relocation closes out the novel. Earlier, Katya somewhat proudly thought of her work as "[p]utting the wild back in the wild, keeping the tame tame," and wondered about having the chance "to reverse the flow, mix it up" (19). But she also voiced concern about the tendency of structures to undermine themselves: "All the wear and tear, the rot and disintegration, the distressing entropy of built things" (30). A plot that loops together a family tragicomedy and an allegorical farce about the pretensions of South African society ends with a paean to transience, interpenetration, and flux:

There is no way to keep the shape of things. One house falls, another rises. Throw a worn brick away and someone downstream will pick it up and lay it next to others in a new course in a new wall — which sooner or later will fall into ruin, giving the spiders a place to anchor their own silken architecture. Even human skin...is porous and infested, every second letting microscopic creatures in and out. Our own bodies are menageries. Short of total sterility, there is no controlling it. (207)

These reflections disclose the fault lines in Rose-Innes's representational approach, as I have been describing it. On one hand, in linking the novel back to the ancient and scriptural topoi of its title, this concluding excursus writes an 
ecological pastoral over its urban setting: structures designed solely for human habitation rise and fall, but spiders, insects, and microorganisms remain. The novel thus circles back to its epigraphs, a lament for the Sumerian city of Ur around $2000 \mathrm{BC}$ and an excerpt from Zephaniah's prophecy contemporaneous with Nineveh's "desolation" (8), which both feature the theme of nonhumans swarming abandoned cities. Rose-Innes confers a venerable ancientness on the urban topos while emphasizing its evanescence. In this existential vision of interspecies braiding, there are no pests or vermin, only organic life in porous relation across time: transient, self-aggregating swarms that mimic those "transits between human bodies and nonhuman natures" that Stacy Alaimo terms "trans-corporeality" (2), ways of resisting "fantasies of transcendence or imperviousness" (17). Beetles (and others) buzz and swarm and plot a course in smooth space.

On the other hand, in a more temporally compressed fashion, the economic fate of the estate tells a story of boundaries redrawn and inequities reestablished. Like the historical Nineveh, the estate is taken over by squatters in its turn, becoming just another hub in the informal market for (stolen) car parts, another of South Africa's “domains of uncertain ownership" (207). ${ }^{29}$ Nineveh's vision of an ecological community in flux strains against a historical topography of place and relocation that is not so straightforwardly backgrounded or "respatialized" (McDonald 99). Smooth space is in tension with the interests of the state, which always looks "to striate the space over which it reigns, or to utilize smooth spaces as a means of communication in the service of striated space" (Deleuze and Guattari 385). For many of Nineveh's actors, nonhuman creatures remain distinct from human projects, and the anxieties expressed in the imaginary of vermin or invasive species can still be deployed for socioeconomic critique. Humans, caught in a historical undertow, strain to find a way out of striated space.

The tension between these levels helps explain why Nineveh easily sustains opposed readings. Some accounts develop the novel's negative register even if its cheerful tone and stylistic buoyancy would seem to argue otherwise. For Shane Graham, Katya's affect often reads as anxious; he usefully points to her "distrust in the stability of built environments" and "anxieties over dissolution and contamination" $(67,71)$. In Graham's reading, the novel's broader "cultural anxieties...are not about entrenched inequalities and panoptical social control, but about invasion and infiltration, entropy and disintegration" (76). Similarly, for Filippo Menozzi, relying on the invasive species trope, the novel undertakes "a poetic remapping of urban geography" that imagines "alternative ways of inhabiting the city," reimagined as "a zone of becoming" (194, 195, 198). Yet if such remapping sometimes undoes "social partition," setting against "technologies of exclusion and division...a line of flight...through which living organisms maintain contacts and relationships" (Menozzi 198), or pointing to "blind spots and interstices" (Graham 71) in the surveillance 
apparatus, these victories might seem transient when viewed at another scale. That is, even if Nineveh trades on themes of "dissolution" and "becoming," it surely also makes clear the striations that thwart migrants even if some get through: walls, borders, checkpoints, and biometrics. One might see RoseInnes as more intrigued by tentative, experimental reconfigurations of urban space, interactions that do not necessarily adjust its deeper structural inequality even if they make it visible. (It is worth noting that one of the novel's "lines of flight" is the drearily familiar scene of transnational impunity for elites: while the other characters remain in South Africa, Mr. Brand emigrates "pursued by bankruptcy and lawsuits" [197], surely never to return.)

In a different interpretation of the novel, more in concert with Rose-Innes's detailed sensitivity to urban ecology and biodiversity, Loren Kruger has placed Nineveh alongside progressive urban planning initiatives as a "contribution to the broader project of imagining, planning and sustaining a more equitable Cape Town" (16). Although this rich account maintains that the novel's "terms of coexistence among species and among different classes of humans remain resolutely social" (28), Kruger's allying of Rose-Innes with the discourse of urban sustainability might overplay Nineveh's buoyant tone as optimism. The novel does, to be sure, end with a "narrative of solidarity" (Kruger 29), but this may not finally dislodge its earlier undercurrents of forced displacement and domestic violence.

During her commission at Nineveh, while browsing at the mall, Katya ponders two books that could summarize the discourses I have been considering, and the divergent readings they elicit: a guide to insect species and an album of then-and-now photographs of Cape Town's dismantled township (or location) District Six (96). At the end of the novel she confronts directly "the bare patch that used to be District Six" (206) and wonders more broadly about the spaces of the post-apartheid metropolis. Every actor in the novel is imagined living "in a subtly different Cape Town, waving to each other, meeting occasionally in the places where such cities overlap. Zones where the world is taking form; where things get mixed up and wander from their positions" (206-07). RoseInnes intimates that these different scenes of overlap are all rightly "Ninevehs" (207). But formal interconnection at the level of language or of the body's microbiome seems rather different from this anodyne vision of communal overlap with social actors "waving to each other" across unequal spaces. Having pursued an analogy between insect migrations and human circuits, reclaiming the first from the dark cast of vermin, rebranding the second in a relocation that furnishes a vision of interspecies community, Rose-Innes might seem, in the end, to leave these representational tensions at something of an impasse. The closing drift of the novel discloses an allegiance to ecological concerns and nonhuman connections over those of social inequality and forced migration, if only by lifting such concerns up to a different, existential register. Rose-Innes's vision of transience, that is, calls forth longer timeframes 
and larger scales than human generations or changing urban precincts. In an interview, she admits that in Nineveh "change is inevitable, irresistible and not necessarily undesirable" ("South African"). Some may see this impasse as a problematic elision of present political struggles. The turn to an ethics of transience, I have been arguing, does remain cognizant of historical and ongoing injustices even as it brings ecological concerns to the fore. Indeed, the growing prominence of such concerns may reflect the eventual political thrust of the recuperative gestures I have been cataloging under the rubric of ecological relocation. Especially in these closing meditations, Nineveh runs a risk in siding with ecological and existential rather than presently political matters. Without sounding the depths of the city or attending to the nonhuman world, these reflections also seem to suggest, cracks in the architecture of human community may one day become too wide to bridge.

\section{HARVARD UNIVERSITY}

\section{NOTES}

${ }^{1}$ See Ambraseys 67-68, in a catalog that includes other earthquakes along this region's so-called North Anatolian fault line (e.g., at Mosul: 292-94). In this paragraph, I rely on the summary sources of Kumrat, Bushinski, Grayson, and Oates.

${ }^{2}$ See Grayson 113 and Oded 54-59 on mass deportations as a source of labor for the Assyrian empire. On Sennacherib's construction projects, see Grayson 113-17.

${ }^{3}$ See Oates 183-84. Nineveh was abandoned after these events, squatters returning occasionally without further repopulation or construction (Oates 181-82).

${ }^{4}$ Rose-Innes has a background in archaeology and paleoanthropology that informs her fiction, particularly in The Rock Alphabet, with its archaeologist protagonist. The "Ninevites," it should also be noted, were an early-twentieth-century criminal outfit operating around the Witwatersrand (van Onselen 175-93).

${ }^{5}$ Citations to Nineveh appear hereafter in parentheses in the text.

${ }^{6}$ Comaroff and Comaroff give a brilliant analysis of the ideological work done by twin discourses about "aliens" - humans and plants — in post-apartheid Cape Town, where "alien plants...transform and represent diffuse political terrors as natural facts" (639). Lidström and colleagues provide a multifaceted account of how tenacious and reductive "invasive alien species" narratives have become in South Africa, "becom[ing] entangled with pervasive cultural and historical concerns about identity, belonging and boundedness" (5). See the essays in Hassim, Kupe, and Worby for perspectives on South Africa's recent xenophobic turn against migrants from other African countries.

${ }^{7}$ See Morton on the "mesh" where "all beings are related to each other negatively and differentially, in an open system without center or edge" (39); Heise 194-201 on "multispecies justice"; and Nixon, Slow Violence 1-44, on the social inequity of ecological threat.

${ }^{8}$ Rose-Innes's short story "Poison," for instance, winner of the South African PEN award (2007) and the Caine Prize for African Writing (2008), focuses on a group of people stranded at a petrol station just outside Cape Town, after a chemical explosion forces the city's evacuation.

${ }^{9}$ For a summary of the characterization of Jews as vermin in Nazi Germany, see Raffles.

${ }^{10}$ As just one among many examples, see Moloi (a hearing for a man whose son was killed in a raid where people were treated "like vermin, absolute vermin").

${ }^{11}$ To schematize: Katya Grubbs and her family are white, as is Martin Brand, whose name, the novel makes explicit, identifies him as Afrikaans (32); Zintle (meaning "beautiful" in Zulu) is 
styled as a member of the upwardly-mobile black bourgeoisie, a commanding, elegant woman, "all arcs and curves, sketched with a calligraphy pen and filled in with rich colour" (36), who has started her own public relations firm at the end of the novel (197).

${ }^{12}$ This strategy finds a related, more explicit form in Rose-Innes's later novel Green Lion, where each chapter title is an organism (e.g., "Dassie," "Quagga," "Stegosaurus").

${ }^{13}$ Anna, the focal character in Rose-Innes's first novel Shark's Egg (2000), "had always scarred easily, carrying marks on her body that recorded a life of petty accident," "a life story written for the fingertips, like Braille" (58). A character in "Burning Buildings," similar to both Anna and Katya, is adept at handling birds (Homing 109-10) and sports "countless scars, marks that life had notched on her body to record this little pain, that small mistake" (113).

${ }^{14}$ Rose-Innes acknowledges the Field Guide to Insects of South Africa, which includes an entry for the "common metallic longhorn" beetle (Promeces longpipes) that lives along much of South Africa's littoral and is described as "metallic green-blue" (Picker, Griffiths, and Weaving 244); roughly this English designation appears in the novel (46).

${ }^{15}$ Again, Green Lion develops these themes of interspecies competition and spatial control at length, taking as its principal setting the reimagined Lion's Den in the now-abandoned Groote Schuur Zoo (originally founded by Cecil Rhodes) at the base of Table Mountain.

${ }^{16}$ In "The Leopard Trap," an interior design graduate on a retreat from her troubled husband, an architect, gains perspectival empathy and "a feeling of inside-outness" on crawling inside an abandoned animal trap (Homing 50). Returning to find their apartment torn up, she considers "a black gap [in the wall] that went down who knew how far-perhaps beyond the concrete and pilings of the building and into the cold earth itself" (51). Another story in Homing, "Falling," focuses on a man who repeatedly scales the glass dome of a Cape Town mall designed by his father, also an architect, trying to reconstruct the memory of an accident he might have caused as a child. The collection's title story, "Homing," follows a woman who gains new vantage on her world by spying on her home while on a clandestine stay in the hotel that now overshadows their block. Kruger sees this story as anticipating Nineveh (23-24).

${ }^{17}$ Graham points out that the novel could be read as "a commentary on citadel urbanism and the privatized security state" (69).

${ }^{18}$ The classic account of "apartheid capitalism's peculiar form of durable inequality" (14) into the 1990s and beyond is Bond's Elite Transition, which notes how "free enterprise and property rights [were] enshrined in every major economic policy statement and the Constitution itself, [and] full blown neoliberal compradorism became the dominant (if not universal) phenomenon within the ANC [African National Congress] policy-making elite" (13-14). I use the terms "neoliberal" and "neoliberalism" mainly to refer to this post-apartheid valorization of private enterprise for addressing public concerns, but see Ferguson for a provocative overview of the term's varying senses in the (South) African context.

${ }^{19}$ Since the 2000s, the tension between "entrepreneurial governing" and "social integration and equity" (Miraftab, "Governing" 617) in neoliberal housing policy has led to forced relocations from areas around Cape Town's Central Business District (e.g., Zonnebloem, Woodstock, Sea Point, Salt River) to crowded areas often far from the city (e.g., Blikkiesdorp, Wolwerivier, Pelikan Park). There have also been many evictions from informal settlements in areas like Khayelitsha, Langa, and (most recently) Elsie's River, with corresponding local resistance. For accounts of these recent practices of gentrification, forced removal, and informal settlement clearing, in the context of South Africa's struggle with post-apartheid housing policy, see Bond 95-117 and Huchzermeyer 112-40, 142-55.

${ }^{20}$ For community resistance and anti-eviction politics, particularly in the context of neoliberal policies pursued by South African governments since 1996, see Desai, We are the Poors 46-55, 94-99; Desai, "Neoliberalism and Resistance"; and Desai and Pithouse.

${ }^{21}$ See, for instance, Christopher and Turok. For analyses of Cape Town's socioeconomic and spatial inequality, under and after apartheid, see Western, Outcast Cape Town and "A Divided City"; McDonald; Samara; and Miraftab, "Colonial Present." McDonald gives the most thorough account of the role of neoliberal ideas in Cape Town's contemporary urban planning (15-47, 6066), a theme also present in other studies. Much of his account (McDonald 99-173) focuses on how reforms designed to "respatialize" the city by overcoming racial disparities in municipal government ended up prioritizing capitalist investment in services for the rich "at the expense of poverty alleviation and township upgrading" (100). Samara offers a related analysis of neoliberal 
governance and its differential approach to crime, security, and urban renewal (1-21, 42-53). For an overview of Cape Town's earlier, purportedly more mixed racial composition, and the emergence of segregation practices in the nineteenth century, see Bickford-Smith.

${ }^{22}$ In a memoir snippet entitled "Semiprecious," published online a year before Nineveh, Rose-Innes writes of coming to realize that her own family's home was once occupied by a non-white family who sold up as others in the neighborhood were probably "forced out to some bleak township to make space for people like us."

${ }^{23}$ The term is the anthropologist Thayer Scudder's, cited by Nixon (Slow Violence 152) in discussing Arundhati Roy's writing and the environmental politics of dam construction in India (150-74). In the South African context, people were sometimes moved "to make way for dams, game reserves, and agricultural developments" (Platzky and Walker 27; see also 46-51).

${ }^{24}$ Under apartheid, "informal settlements" denoted areas "not planned or approved by the local authorities or the State," where housing was built "generally out of unorthodox building materials" (Platzky and Walker xii). The term persists as a more neutral alternative to the one favored in recent development parlance: "slum" (see Huchzermeyer 5-9).

${ }^{25}$ Titlestad gives an excellent overview and taxonomy of urban representation in South African literature from the 1950s through the post-apartheid era.

${ }^{26}$ For more on these concepts, see Deleuze and Guattari 413-15, 474-500. Menozzi's reading of the novel also relies on the work of Deleuze and Guattari, making use of the distinct but related concept of "deterritorialization."

${ }^{27}$ Rose-Innes's figures of spatial dislocation match other representations of urban space in contemporary literature, especially when sited in Johannesburg and not Cape Town. See WestPavlov's account of an "inside out" logic in novels by Phaswane Mpe and Ivan Vladislavić.

${ }^{28}$ In this, the novel is in keeping with a growing attention to nonhumans in the discipline of urban geography: see Wolch and Philo.

${ }^{29}$ The estate's fate underlines what has been termed - in a reading of the novel Zoo City by RoseInnes's contemporary Lauren Beukes - the "existential horizon" of infrastructure, its quality of being "inherently riven by incompatible temporal registers" (Eatough 692, 709).

\section{WORKS CITED}

Alaimo, Stacy. Bodily Natures: Science, Environment, and the Material Self. Bloomington: Indiana UP, 2010.

Ambraseys, Nicholas. Earthquakes in the Mediterranean and Middle East: A Multidisciplinary Study of Seismicity up to 1900. Cambridge: Cambridge UP, 2009.

Bady, Aaron. "None of You [Rev. of Nineveh, by Henrietta Rose-Innes]." Zunguzungu Blog, The New Inquiry. Web. 28 Nov. 2016.

Beinart, William. The Rise of Conservation in South Africa: Settlers, Livestock, and the Environment 1770-1950. Oxford: Oxford UP, 2003.

Bickford-Smith, Vivian. "South African Urban History, Racial Segregation and the Unique Case of Cape Town?" Journal of Southern African Studies 21.1 (1995): 63-78.

Bond, Patrick. Elite Transition: From Apartheid to Neoliberalism in South Africa. Rev. ed. London: Pluto, 2014.

Christopher, A. J. "The Slow Pace of Desegregation in South African Cities, 1996-2001." Urban Studies 42.12 (2005): 2305-20.

Coetzee, J. M. Age of Iron. New York: Penguin, 1990.

—. Dusklands. 1974. New York: Penguin, 1996.

—. Foe. 1986. New York: Penguin, 1988.

—. Life \& Times of Michael K. 1983. New York: Penguin, 1984

—. The Lives of Animals. Ed. Amy Gutmann. Princeton: Princeton UP, 1999.

—. Waiting for the Barbarians. 1980. New York: Penguin, 1982.

Comaroff, Jean, and John L. Comaroff. "Naturing the Nation: Aliens, Apocalypse and the Postcolonial State." Journal of Southern African Studies 27.3 (2001): 627-51.

Deleuze, Gilles, and Félix Guattari. A Thousand Plateaus: Capitalism and Schizophrenia. Trans. Brian Massumi. Minneapolis: U of Minnesota P, 1987. 
Desai, Ashwin. "Neoliberalism and Resistance in South Africa." Monthly Review 54.8 (2003): 16-28.

-. We are the Poors: Community Struggles in Post-Apartheid South Africa. New York: Monthly Review, 2002.

Desai, Ashwin, and Richard Pithouse. "What Stank in the Past Is the Present's Perfume': Dispossession, Resistance, and Repression in Mandela Park." South Atlantic Quarterly 103.4 (2004): 841-75.

Desmond, Cosmas. The Discarded People: An Account of African Resettlement in South Africa. Harmondsworth, UK: Penguin, 1970.

Eatough, Matthew. "Planning the Future: Scenario Planning, Infrastructural Time, and South African Fiction.” Modern Fiction Studies 61.4 (2015): 690-714.

Fugard, Athol, John Kani, and Winston Ntshona. Sizwe Bansi is Dead. The Township Plays. Ed. Dennis Walder. Oxford: Oxford UP, 1993. 147-92.

Gordimer, Nadine. A Guest of Honour. 1970. London: Bloomsbury, 2002.

—. July's People. 1981. New York: Penguin, 1982.

—. "The Soft Voice of the Serpent." Life Times: Stories, 1952-2007. New York: Farrar, Straus and Giroux, 2010. 3-8.

- A Sport of Nature. 1987. London: Bloomsbury, 2013.

Graham, Shane. "The Entropy of Built Things: Postapartheid Anxiety and the Production of Space in Henrietta Rose-Innes' Nineveh and Lauren Beukes' Zoo City.” Safundi 16.1 (2014): 64-77.

Grayson, A. K. "Assyria: Sennacherib and Esarhaddon (704-669 B.C.)." The Assyrian and Babylonian Empires and Other States of the Near East, from the Eighth to the Sixth Centuries B.C. 2nd ed. Ed. John Boardman, I. E. S. Edwards, E. Sollberger, N. G. L. Hammond. Vol. 3, Pt. 2 of The Cambridge Ancient History. Cambridge: Cambridge UP, 1992. 103-41.

Ferguson, James. "The Uses of Neoliberalism." Antipode 41.1 (2009): 166-84.

Hassim, Shireen, Tawana Kupe, and Eric Worby, eds. Go Home or Die Here: Violence, Xenophobia, and the Reinvention of Difference in South Africa. Johannesburg: Wits UP, 2008.

Heise, Ursula K. Imagining Extinction: The Cultural Meanings of Endangered Species. Chicago: U of Chicago P, 2016.

Huchzermeyer, Marie. Cities with 'Slums': From Informal Settlement Eradication to a Right to the City in Africa. Cape Town: U of Cape Town P, 2011.

Kamrat, Yuval. "Nineveh." Encyclopaedia Judaica. Ed. Michael Berenbaum and Fred Skolnik. 2nd ed. Vol. 15. Detroit: Macmillan Reference USA, 2007. 271-72.

Kruger, Loren. "Cape Town and the Sustainable City in the Writing of Henrietta Rose-Innes." Journal of Urban Cultural Studies 2.1 (2015): 15-33.

La Guma, Alex. A Walk in the Night, and Other Stories. Evanston: Northwestern UP, 1968.

Lidström, Susanna, Simon West, Tania Katzschner, M. Isabel Pérez-Ramos, and Hedley Twidle. "Invasive Narratives and the Inverse of Slow Violence: Alien Species in Science and Society." Environmental Humanities 7 (2015): 1-40.

McDonald, David A. World City Syndrome: Neoliberalism and Inequality in Cape Town. New York: Routledge, 2008.

Menozzi, Filippo. "Invasive Species and the Territorial Machine: Shifting Interfaces Between Ecology and the Postcolonial." Ariel 44.4 (2014): 181-204.

Miraftab, Faranak. "Colonial Present: Legacies of the Past in Contemporary Urban Practices in Cape Town, South Africa.” Journal of Planning History 11.4 (2012): 283-307.

- "Governing Post-Apartheid Spatiality: Implementing City Improvement Districts in Cape Town." Antipode 39.4 (2007): 602-26.

Moloi, Stephan C. F. “Amnesty Hearing.” Truth and Reconciliation Commission. Web. 3 Jul. 1997.

Morton, Timothy. The Environmental Thought. Cambridge: Harvard UP, 2010.

Nixon, Rob. "Neoliberalism, Genre, and 'The Tragedy of the Commons." PMLA 127.3 (2012): 593-99.

—. Slow Violence and the Environmentalism of the Poor. Cambridge: Harvard UP, 2011.

Oates, Joan. "The Fall of Assyria (635-609 B.C.)." The Assyrian and Babylonian Empires and Other States of the Near East, from the Eighth to the Sixth Centuries B.C. 2nd ed. Ed. John Boardman, I. E. S. Edwards, E. Sollberger, N. G. L. Hammond. Vol. 3, Pt. 2 of The Cambridge Ancient History. Cambridge: Cambridge UP, 1992. 162-93. 
Oded, Bustenay. Mass Deportations and Deportees in the Neo-Assyrian Empire. Wiesbaden: Reichert, 1979.

Philo, Chris. "Animals, Geography, and the City: Notes on Inclusions and Exclusions." Environment and Planning D: Society and Space 13.6 (1995): 655-81.

Picker, Mike, Charles Griffiths, and Alan Weaving. Field Guide to Insects of South Africa. Cape Town: Struik, 2002.

Platzky, Laurine, and Cherryl Walker. The Surplus People: Forced Removals in South Africa. Johannesburg: Ravan, 1985.

Raffles, Hugh. "Jews, Lice, and History." Public Culture 19.3 (2007): 521-66.

Rose-Innes, Henrietta. Green Lion. Cape Town: Umuzi, 2015.

-. Homing. Cape Town: Umuzi, 2010.

—. Nineveh. Cape Town: Umuzi, 2011.

—. The Rock Alphabet. Cape Town: Kwela, 2004.

—. "Semiprecious." Granta 111: Going Back. Web. 5 Aug. 2010.

-. Shark's Egg. Cape Town: Kwela, 2000.

—. "South African Writer Henrietta Rose-Innes's Nineveh [Interview with Brian Davidson]." Africa Is a Country. Web. 18 Apr. 2012.

Samara, Tony Roshan. Cape Town after Apartheid: Crime and Governance in the Divided City. Minneapolis: U of Minnesota P, 2011.

Senghor, Léopold Sédar. On African Socialism. Trans. Mercer Cook. New York: Praeger, 1964.

Swanson, Maynard W. "The Sanitation Syndrome: Bubonic Plague and Urban Native Policy in the Cape Colony, 1900-09." Journal of African History 18.3 (1977): 387-410.

Titlestad, Michael. "Writing the City after Apartheid." The Cambridge History of South African Literature. Ed. David Attwell and Derek Attridge. Cambridge: Cambridge UP, 2012. 676-94.

Turok, Ivan. "Persistent Polarisation Post-Apartheid? Progress Towards Urban Integration in Cape Town." Urban Studies 38.13 (2001): 2349-77.

Twidle, Hedley. "Rachel Carson and the Perils of Simplicity: Reading Silent Spring from the Global South." Ariel 44.4 (2013): 49-88.

Van Onselen, Charles. New Nineveh. Vol. 2 of Studies in the Social and Economic History of the Witwatersrand, 1886-1914. Johannesburg: Ravan, 1982.

Van Sittert, Lance. "Keeping the Enemy at Bay': The Extermination of Wild Carnivora in the Cape Colony, 1889-1910." Environmental History 3.3 (1998): 333-56.

-. "Routinising Genocide: The Politics and Practice of Vermin Extermination in the Cape Province c. 1889-1994." Journal of Contemporary African Studies 34.1 (2016): 111-28.

Western, John. “A Divided City: Cape Town.” Political Geography 21 (2002): 711-16.

-. Outcast Cape Town. Berkeley: U of California P, 1996.

West-Pavlov, Russell. "Inside Out: The New Literary Geographies of the Post-Apartheid City in Mpe's and Vladislavic's Johannesburg Writing.” Journal of Southern African Studies 40.1 (2014): 7-19.

Wolch, Jennifer. “Anima Urbis.” Progress in Human Geography 26.6 (2002): 721-42. 